\title{
Genetic and Clinical Spectrum of Aromatase Deficiency in Infancy, Childhood and Adolescence
}

\author{
A. Belgorosky G. Guercio C.Pepe N.Saraco M.A. Rivarola \\ Endocrine Service, Hospital de Pediatria Garrahan, Buenos Aires, Argentina
}

\section{Key Words}

Androgen excess · Aromatase deficiency $\cdot$ Estrogen replacement $\cdot$ Hypothalamo-pituitary-gonadal axis · Insulin insensitivity

\begin{abstract}
Introduction: CP450aromatase deficiency provides clues for the understanding of the role of aromatase in prepubertal and pubertal human health and disease. Placental aromatization of androgens protects the female fetus against the virilizing action of fetal androgens. After birth, the dual effect of aromatase deficiency, excessive androgens, and insufficient estrogens is responsible for a variable clinical picture. Nineteen cases of aromatase gene (CYP19) deficiency have been reported. Phenotype: Phenotype is dependent on sex and age. In newborns, aromatase deficiency should be considered in the etiology of $46, X X$ DSD, after ruling out congenital adrenal hyperplasia. In prepubertal aromatase deficient girls, high levels of ovarian androgens and gonadotropins facilitate the formation of ovarian cysts. Bone mineralization can be affected and bone aging is delayed. In pubertal girls, there is poor sexual development and abnormal virilization. The phenotype may be variable according to enzyme activity level. Insulin sensitivity may be abnormal in
\end{abstract}

both men and women. Finally, aromatase might also play a role in the regulation of testicular cell mass in the newborn testis. Conclusion: Adequate interpretation of clinical data should lead to the analysis of the CYP19 gene for diagnostic confirmation and implementation of appropriate management.

Copyright $\odot 2009$ S. Karger AG, Basel

Several molecular CYP19 gene alterations associated with cytochrome P450aromatase (cP450arom) deficiency have been described in both females and males. They have contributed considerably to the analysis of $\mathrm{cP}$ 450arom activity in different tissues, influencing sexual differentiation, patterns of gonadotropin secretion by the hypothalamic-pituitary axis, reproduction capacity, lipid metabolism, insulin sensitivity, and skeletal maturation and growth. Several reviews of this rare disorder have been published [1-4] addressing mainly the clinical picture in affected adult men [4-6].

This review discusses clinical, biochemical and molecular aspects of human cP450arom deficiency during childhood in both sexes and in affected pubertal subjects.

\section{KARGER}

Fax +4161306 1234 E-Mail karger@karger.ch www.karger.com (c) 2009 S. Karger AG, Basel

0301-0163/09/0726-0321\$26.00/0

Accessible online at:

www.karger.com/hre
Alicia Belgorosky, $\mathrm{MD}, \mathrm{PhD}$

Endocrinology Service, Hospital de Pediatria Garrahan

C. de los Pozos 1881

Buenos Aires C1245AAM (Argentina)

Tel. +54 114308 0034, Fax +54 114308 5325, E-Mail abelgo@ elsitio.net 
Fig. 1. The human CYP19 (cP450arom) gene, located in the 21.2 region on the long arm of chromosome 15 (15q21.2). Its regulatory region contains at least 10 distinct promoters regulated in a tissue- or signaling pathway-specific manner. The coding exons, namely exons II-X, are shown, along with the location of the reported mutations.

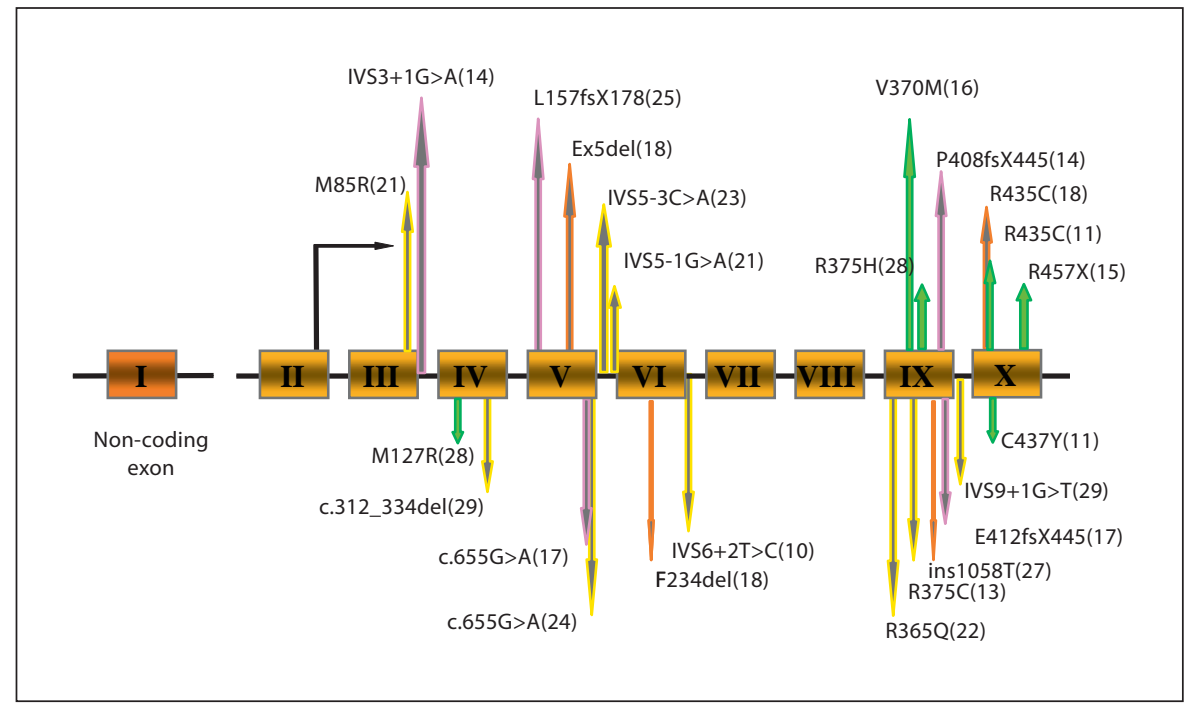

\section{cp450arom Characteristics and Reported Human Mutations}

cP450arom is the enzyme that catalyses the synthesis of estrogens from androgens. Therefore, the activity of this enzyme complex affects both androgen metabolism and estrogen synthesis. The biological importance of the aromatase complex is related not only to its role in the synthesis of estrogens, but also to its potential influence on the balance of the androgen-estrogen ratio in different tissues. The aromatase complex is expressed in the endoplasmic reticulum of cells, and consists of 2 components: cP450arom and a ubiquitous flavoprotein, NADPH-cytochrome $\mathrm{P} 450$ reductase. Even though androstenedione and testosterone are the most common and the most physiologically important substrates, $16 \mathrm{OH}$-dehydroepiandrosterone sulfate (16OH-DHEAS) arising from fetal liver hydroxylation of fetal adrenal DHEAS is an important substrate for placental estriol synthesis during pregnancy, both in humans and higher primates [1].

In humans, $\mathrm{cP} 450$ arom appears to be the product of a single gene - CYP19 - located on chromosome 15q21.1. The protein-coding sequence is contained within 9 exons (2-10), that span approximately $35 \mathrm{~kb}$ of DNA [7]. The translation, initiation and termination codons are present between exons 2 and 10. However, there are multiple first exons that are involved in tissue-specific expression. These exons, that are not translated, generate alternative splicing in such a fashion that the coding region, and hence the protein sequence, is conserved in every tissue. Several promoters are found within a $90-\mathrm{kb}$ region up- stream of the coding region [7]. The most highly conserved region (the core region), defined by a 3-dimensional model of cP450arom, consists essentially of a 4-helix bundle, $2 \beta$ sheets and the heme-binding region.

cP450arom is expressed in a number of tissues, including the syncytiotrophoblast layer of the placenta, gonads, adipose tissue, bone, brain (including the hypothalamus, hippocampus, and amygdala), coronary arteries, and various fetal tissues, such as liver, skin, intestine, testis and ovary [8].

CYP19 gene expression is subjected to multifactor regulation by a diverse group of hormones and factors that differ markedly between tissues. Thus, a strict control over tissue-specific expression is necessary for proper regulation of estrogen synthesis during fetal development, as well as during post-natal life.

Since aromatase deficiency was first described by Shozu et al. in 1991 [9], 19 cases have been reported (11 females [9-21] and 8 males [13, 22-29]). Molecular defects, in vitro aromatase activity of mutants, and clinical phenotype in subjects who were of pre-pubertal or pubertal age at diagnosis are described in table 1 . Variations in phenotype are compared with in vitro functional derangements of mutants. Table 2 shows molecular defects and in vitro aromatase activity in subjects who were adults at diagnosis. Curiously, all reported adult subjects were males in whom the main phenotypic characteristics are tall stature and varying degrees of mild testicular hypofunction. Figure 1 shows a cartoon of the cP450arom gene with its exons, depicting the main mutations described so far in humans. 
Table 1. Mutations of the CYP19 gene reported in subjects who were of pre-pubertal or pubertal age at diagnosis

\begin{tabular}{|c|c|c|c|c|}
\hline Sex [ref.] & Gene mutations & Molecular defect & In vitro aromatase activity & Phenotype \\
\hline Female [10] & $\begin{array}{l}\text { Homozygous } \\
(\mathrm{hm}) \\
\text { IVS } 6+2 \mathrm{~T}>\mathrm{C}\end{array}$ & $\begin{array}{l}\text { Mutation at consensus } 5^{\prime} \text { splice site }\left(5^{\prime} \text { ss) }\right. \\
\text { in intron } 6 \text { resulting in the use of a cryptic } \\
\text { site downstream and in the in-frame } \\
\text { incorporation of } 87 \text { nucleotides. } \\
\text { A protein with additional highly hydro- } \\
\text { phobic } 29 \text { amino acids will be generated. }\end{array}$ & $\begin{array}{l}\text { Less than } 0.3 \% \text { of WT control. } \\
\text { The extra aa might induce } \\
\text { conformational changes and reduction } \\
\text { of activity. }\end{array}$ & Ambiguous genitalia at birth. \\
\hline Female [11] & $\begin{array}{l}\text { Compound } \\
\text { heterozygous: } \\
\text { R435C } \\
\text { C437Y }\end{array}$ & $\begin{array}{l}\text { R435C: Cysteine instead of arginine at } \\
\text { codon } 435 \text {, exon } 10 \text {. Highly conserved } \\
\text { residue within the heme-binding region } \\
\text { among cP450s. } \\
\text { C437Y: tyrosine instead of cysteine at } \\
\text { position } 437 \text {, exon } 10 \text {. Cysteine } 437 \text { is the } \\
\text { critical cysteine in the heme-binding } \\
\text { domain and is the best conserved residue in } \\
\text { all cP450 proteins [8]. }\end{array}$ & $\begin{array}{l}\text { R435C mutant protein showed } \\
\text { approximately } 1.1 \% \text { of WT activity. } \\
\text { C437Y mutant protein was inactive. }\end{array}$ & $\begin{array}{l}\text { Ambiguous genitalia at birth. } \\
\text { Puberty absent. } \\
\text { Delayed bone age, ovarian cyst and } \\
\text { virilizing signs at pubertal age. }\end{array}$ \\
\hline Female [13] & hm R375C & $\begin{array}{l}\text { Exon } 9 \text { mutation, a cysteine instead of an } \\
\text { arginine }\end{array}$ & $\begin{array}{l}0.2 \% \text { of WT activity. } \\
\text { Protein modeling studies suggest that } \\
\text { the affected region may affect the } \\
\text { substrate access channel to the } \\
\text { membrane. }\end{array}$ & $\begin{array}{l}\text { Ambiguous genitalia at birth. } \\
\text { Puberty absent. } \\
\text { Ovarian cyst and virilizing signs at } \\
\text { pubertal age. }\end{array}$ \\
\hline Female [15] & hm R457X & $\begin{array}{l}\text { Point mutation in exon } 10 \text { generating a } \\
\text { premature stop codon. }\end{array}$ & Not determined. & No detailed phenotype reported. \\
\hline Female [14] & $\begin{array}{l}\text { Compound } \\
\text { heterozygous: } \\
\text { P408fsX445 } \\
\text { IVS3+1G>A }\end{array}$ & $\begin{array}{l}\text { P408fsX445: A base pair deletion (C) in } \\
\text { codon } 408 \text { (exon 9). A frameshift occurs } \\
\text { resulting in a nonsense codon. } \\
\text { IVS3+1G>A: G to A change at the } \\
\text { canonical donor splice site in intron } 3 \text {. } \\
\text { The splice site is ignored, and a stop } \\
\text { codon arises } 3 \text { bp downstream. } \\
\text { No active transcript was found. }\end{array}$ & $\begin{array}{l}\text { Not determined. However, no } \\
\text { aromatase activity is expected. }\end{array}$ & $\begin{array}{l}\text { Ambiguous genitalia at birth. } \\
\text { Ovarian cysts during infancy and } \\
\text { childhood. } \\
\text { Low BMD at } 3.5 \text { years of age. }\end{array}$ \\
\hline Female [16] & hm V370M & $\begin{array}{l}\text { G to A transition in exon } 9 \text { that results } \\
\text { in the amino acid change valine to } \\
\text { methionine. }\end{array}$ & Not determined. & Ambiguous genitalia at birth. \\
\hline $\begin{array}{l}\text { Female } \\
\text { infant } \\
{[17,19]}\end{array}$ & $\begin{array}{l}\text { Compound } \\
\text { heterozygous: } \\
\text { C655G }>\text { A } \\
\text { E412fsX445 }\end{array}$ & $\begin{array}{l}\text { E412fsX445: a bp deletion (A) in glu } 412 \\
\text { (exon 9) causing a frame shift generating a } \\
\text { stop codon } 98 \text { bp downstream. } \\
\text { Subsequently, a truncated protein with an } \\
\text { altered heme-binding domain might be } \\
\text { generated. } \\
\text { C655G }>\text { A: G to A at the consensus donor } \\
\text { splice site in exon } 5 \text { to intron } 5 \text { junction } \\
\text { causing in-frame exon } 5 \text { skipping and a } \\
\text { putative inactive protein lacking amino } \\
\text { acids } 151-209 \text { encoded by exon } 5 \text { [11]. }\end{array}$ & $\begin{array}{l}\text { The peptide expressed from E412fsX } 445 \\
\text { is expected to be completely inactive as } \\
\text { the frame shift altered the highly } \\
\text { conserved heme-binding domain. } \\
\text { The protein without amino acids } \\
\text { 151-209 encoded by exon } 5 \text { does not } \\
\text { have aromatase activity. } \\
\text { As the -E5 mRNA might be expressed } \\
\text { as a splice variant in normal tissues, } \\
\text { some + E5 transcripts from the } \\
\text { C655G }>\text { A allele might explain the } \\
\text { partial aromatase deficiency phenotype. }\end{array}$ & $\begin{array}{l}\text { Ambiguous genitalia at birth. } \\
\text { Ovarian cysts during infancy, } \\
\text { childhood and puberty. } \\
\text { Delayed bone age during childhood. } \\
\text { Spontaneous breast development at } \\
7.7 \text { years old. } \\
\text { Virilizing signs at pubertal age. } \\
\text { Normal BMD during infancy, } \\
\text { childhood and puberty. } \\
\text { Insulin resistance since } 7.2 \text { years of } \\
\text { age and Type } 2 \text { diabetes during } \\
\text { follow-up. }\end{array}$ \\
\hline $\begin{array}{l}\text { Pubertal } \\
\text { female [18] }\end{array}$ & hm R435C & $\begin{array}{l}\text { Cysteine instead of arginine at position } 435 \\
\text { in exon X. }\end{array}$ & $\begin{array}{l}0.7-1.5 \% \text { of WT activity. } \\
\text { The arginine at position } 435 \text { forms } \\
\text { part of the absolutely conserved } \\
\text { heme-binding motif and is absolutely } \\
\text { conserved. }\end{array}$ & $\begin{array}{l}\text { Ambiguous genitalia at birth. } \\
\text { Ovarian cysts and delayed bone age. } \\
\text { Spontaneous breast development. }\end{array}$ \\
\hline $\begin{array}{l}\text { Female } \\
\text { infant followed } \\
\text { through } \\
\text { puberty [18] }\end{array}$ & hm F234del & $\begin{array}{l}\text { Deletion of } 1 \text { of } 2 \text { phenylalanines at position } \\
234-235 \text { in exon VI. } \\
\text { This pair of amino acids is highly conserved } \\
\text { in cP } 450 \text { aromatase of other species. }\end{array}$ & $\begin{array}{l}\text { 16-19\% of WT activity. } \\
\text { Substrate binding seems to be largely } \\
\text { unaffected but maximal enzymatic } \\
\text { activity is reduced. } \\
\text { The resultant protein was found to be } \\
\text { completely inactive. }\end{array}$ & $\begin{array}{l}\text { Ambiguous genitalia at birth. } \\
\text { Low androgens levels in a female } \\
\text { infant. } \\
\text { Spontaneous puberty, delayed bone } \\
\text { age and ovarian cysts in a pubertal } \\
\text { female. Severe virilization (raised as } \\
\text { male). }\end{array}$ \\
\hline
\end{tabular}


Table 1 (continued)

\begin{tabular}{|c|c|c|c|c|}
\hline Sex [ref.] & Gene mutations & Molecular defect & In vitro aromatase activity & Phenotype \\
\hline $\begin{array}{l}\text { Pubertal } \\
\text { female [18] }\end{array}$ & hm EX5del & $\begin{array}{l}600 \text { bp deletion at genomic DNA. } \\
\text { This deletion is predicted to remove exon } 5 \\
\text { resulting in the in-frame deletion of } 59 \\
\text { amino acids. }\end{array}$ & $\begin{array}{l}\text { Not determined. } \\
\text { However, no aromatase activity is } \\
\text { expected. }\end{array}$ & $\begin{array}{l}\text { Labial fusion at birth. } \\
\text { Delayed puberty and bone age. } \\
\text { Small ovaries. } \\
\text { Low androgen levels. } \\
\text { Moderate dyslipidemia. }\end{array}$ \\
\hline Female [21] & $\begin{array}{l}\text { Compound } \\
\text { heterozygous: } \\
\text { M85R } \\
\text { IVS5-1G>A }\end{array}$ & $\begin{array}{l}\text { M85R: arginine instead of methionine at } \\
\text { codon } 85 \text { (exon } 3) \text {. }\end{array}$ & $\begin{array}{l}\text { The protein expressed from the M85R } \\
\text { allele showed no activity. }\end{array}$ & $\begin{array}{l}\text { Ambiguous genitalia at birth. } \\
\text { Puberty absent and bone aging } \\
\text { delayed. } \\
\text { Virilizing signs at pubertal age. }\end{array}$ \\
\hline $\begin{array}{l}\text { Male infant } \\
{[25]}\end{array}$ & hm L157fsX178 & $\begin{array}{l}\text { C base deletion in exon } 5 \text { causing a frame } \\
\text { shift and a premature stop codon after } 21 \\
\text { codons. }\end{array}$ & $\begin{array}{l}\text { Not determined. } \\
\text { However, the resultant peptide does not } \\
\text { contain the substrate binding pocket } \\
\text { (I helix), the electron accepting site and } \\
\text { the heme-binding site [21]. }\end{array}$ & Normal genitalia at birth. \\
\hline
\end{tabular}

$\mathrm{BMD}=$ Bone mineral density $; \mathrm{WT}=$ wild type

Table 2. Mutations of the CYP19 gene reported in subjects who were adults at diagnosis

\begin{tabular}{llll}
\hline Sex [ref.] & Gene mutations & Molecular defect & In vitro aromatase activity \\
\hline Male [13] & hm R375C & $\begin{array}{l}\text { Exon 9 mutation resulting in cysteine instead of arginine } \\
\text { at codon 375. }\end{array}$ & $\begin{array}{l}\text { Activity of the mutant protein was 0.2\% of wild type. } \\
\text { Protein modeling studies suggest that the affected region } \\
\text { may be important in anchoring the region of the protein } \\
\text { proximal to the substrate access channel to the membrane. }\end{array}$ \\
\hline Male [22] & hm R365Q & $\begin{array}{l}\text { G to A mutation at base pair 1094 in exon 9 resulting in } \\
\text { glutamine instead of arginine at codon 365. }\end{array}$ & Activity of the mutant protein was 0.4\% of wild type. \\
\hline Male [23] & hm IVS5-3C $>$ A & $\begin{array}{l}\text { C to A transition at bp -3 at the splicing acceptor site in } \\
\text { exon VI. Exon VI is completely excised leading to a } \\
\text { frame shift and premature stop codon 8 nucleotides } \\
\text { downstream from the end of exon 5. }\end{array}$ & $\begin{array}{l}\text { The resulting peptide most likely will not be processed, } \\
\text { but even if it were, it would not result in a functional } \\
\text { aromatase because it lacks the substrate-binding pocket, } \\
\text { the electron-accepting site and the heme-binding site [23]. }\end{array}$ \\
\hline Male [27] & hm Ins1058T & $\begin{array}{l}\text { Tinsertion at nucleotide 1058 in exon 9. This insertion } \\
\text { leads to a frame shift and the appearance of a premature } \\
\text { stop codon 24 codons later. }\end{array}$ & $\begin{array}{l}\text { The protein is expected to be inactive as the heme and } \\
\text { steroid-binding domain would not be present. }\end{array}$ \\
& & stome
\end{tabular}

Male [24] hm c655G $>\mathrm{A} \quad \mathrm{G}$ to A transition in the last nucleotide in exon 5

Not determined. A truncated and inactive protein lacking The mutated DNA will generate an mRNA that includes the intron 5 sequence which contains an in-frame stop codon 30 bp downstream of the splice junction.

\begin{tabular}{llll}
\hline Male [28] & $\begin{array}{l}\text { Compound } \\
\text { heterozygous: } \\
\text { M127R } \\
\text { R375H }\end{array}$ & $\begin{array}{l}\text { M127R: Arginine instead of methionine at codon } 127 \\
\text { (exon IV). }\end{array}$ & $\begin{array}{l}\text { R375H: histidine instead of arginine at codon } 375 \\
\text { (exon IX). }\end{array}$ \\
\hline Male [29] & $\begin{array}{l}\text { Compound } \\
\text { heterozygous: } \\
\text { c.312_334del } \\
\text { IVS9+1G>T }\end{array}$ & $\begin{array}{l}\text { c.312_334del: 23-bp deletion in exon 4 that would be } \\
\text { expected to cause a frame shift with a premature stop } \\
\text { codon at nucleotide 361 in exon 4. }\end{array}$ & $\begin{array}{l}\text { Not determined. A truncated and inactive protein lacking } \\
\text { IVS9+1G }>\text { T: point mutation in the first nucleotide of } \\
\text { intron IX that would lead to aberrant splicing of the } \\
\text { mRNA. }\end{array}$ \\
\end{tabular}


Fig. 2. Compartmentalization of sex hormone metabolism in the feto-placental unit. DHEAS and $16 \alpha \mathrm{OH}-\mathrm{DHEAS}$, synthesized in large amounts by interactions of fetal adrenal gland and liver, are transferred to the placenta. Here, after sulfate hydrolysis and dehydrogenation, active androgens are produced. One important role of aromatase is to neutralize these androgens by converting them into estrogens. In aromatase deficiency, androgens accumulate and virilize the female fetus and the mother.

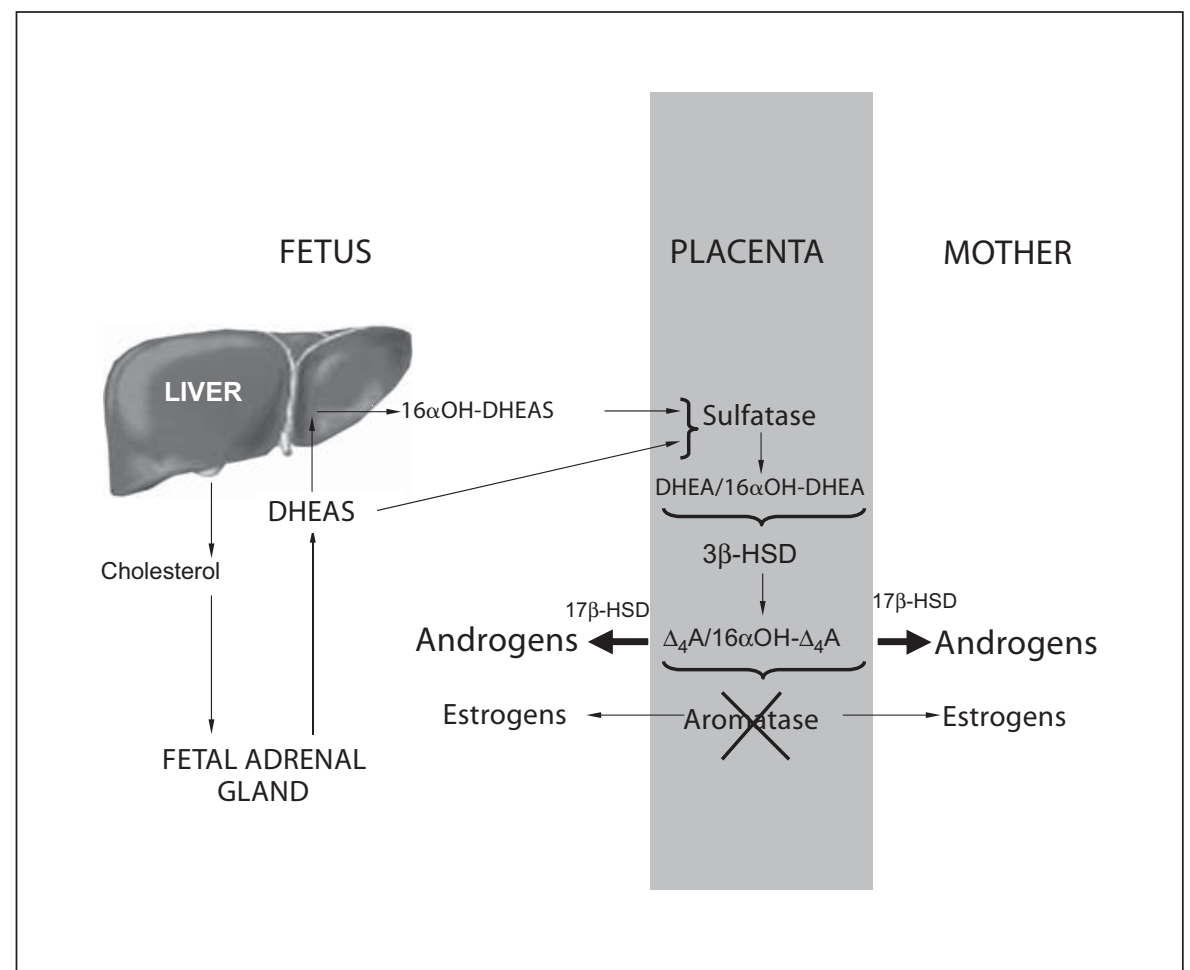

\section{Impact of Aromatase Deficiency}

The clinical characteristics reported in female patients with aromatase deficiency during pre-puberty and puberty, as well as estrogen replacement therapy and the impact of insulin sensitivity, are reviewed in this section. For comparison, the only male infant reported is also discussed.

\section{Female Newborns}

The active human placental aromatization of androgens protects the fetus against the virilizing action of fetal androgens (fig. 2). In the female fetus, this is particularly important to avoid the effect of androgens on differentiation of external genitalia. It also plays a role in the central nervous system, in programming the brain during fetal and neonatal life for noncyclic hypothalamic GnRH function, as well as male sexual identity and behavior. In most female cases of aromatase deficiency described, ambiguous genitalia with various degrees of masculinization of the external genitalia have been reported. As expected, gonads were nonpalpable and female internal genitalia differentiation was not affected $[9,11,13,17-19$, 21]. In addition, signs of maternal virilization (acne, deep voice, clitoris enlargement) during pregnancy might oc- cur and this should alert obstetricians to the possibility of this diagnosis. After delivery, these signs and symptoms disappear gradually $[9,13-14,17-19,21]$. Onset of labor has been described as spontaneous $[9,14]$ and babies were born full term with adequate weight for gestational age $[9,11,13-14,17]$.

In a newborn with 46,XX ambiguous genitalia, the diagnosis of congenital adrenal hyperplasia should be ruled out first, because of its high frequency. However, detecting signs of virilization in the mother is useful clinical information in aromatase deficiency, as it does not occur in congenital adrenal hyperplasia.

An endocrinological profile has been described in some affected females during the first month of postnatal life. High androgen levels in cord serum have been reported, but serum levels of androgens returned rapidly to normal after delivery in some cases $[9,12,14]$. The serum patterns of basal gonadotropins during this period have been reported in only 1 aromatase-deficient girl by Belgorosky et al. [17]. In this patient, serum LH and FSH levels were extremely high, resulting in high serum androgen levels. This abnormal serum gonadotropin pattern might reflect a central change in the activity of the GnRH pulse generator and/or an effect at the pituitary level, presumably induced by the increment of androgens 
Fig. 3. Serum LH, FSH, androstendione (4A) and testosterone ( $\mathrm{T}$ ) during the first year of life in an aromatase-deficient girl. The figure shows extremely high serum $\mathrm{LH}, \mathrm{FSH}, 4 \mathrm{~A}$ and $\mathrm{T}$ during the first 5 months of life, followed by a marked decrease thereafter. However, serum FSH never reached normal levels. A large ovarian cyst was removed at 5 months of age (arrow) coinciding with a huge increase of 4A and T. Hormone values decreased after cyst removal. Shaded areas depict normal ranges for the 4 hormonal determinations. Copyright (C) 2003 The Endocrine Society.
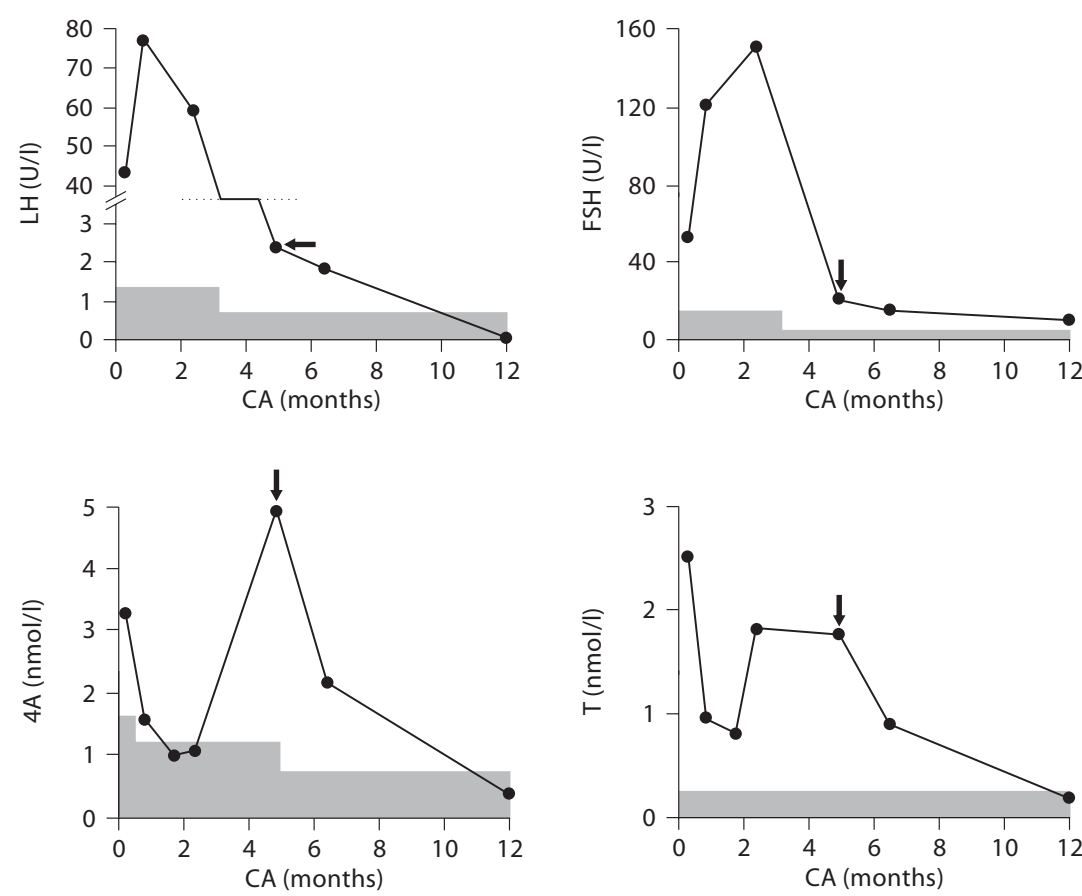

and/or local estrogen deficiency during fetal and neonatal life (fig. 3).

\section{Female Infancy and Childhood}

A clinical phenotype, including changes in the hypothalamic-pituitary-gonadal axis, ovarian cyst development, impact on growth, skeletal maturation, and bone homeostasis, as well as changes in insulin sensitivity and lipid profile, has been reported in affected girls.

\section{Hypothalamic-Pituitary-Gonadal Axis}

The hypothalamic-pituitary-gonadal axis has been studied in 5 affected girls with aromatase deficiency during infancy and childhood [11, 14-15, 17, 18].

In one girl, reported by Belgorosky et al. [17], serum basal FSH and LH levels dropped dramatically between 2 and 6 months of age, but whereas serum basal FSH levels remained clearly high, serum basal LH levels decreased gradually to reach normal levels at the end of the first year of life. On the other hand, during the same age period, basal levels of serum androgens remained high and multiple follicular cysts developed in both ovaries (fig. 3). However, serum androgen levels dropped after a large ovarian cyst was removed. In another girl, reported by Mullis et al. [14], basal serum FSH levels and the FSH response to $\mathrm{GnRH}$ were elevated at 2 months of age, but normal basal and GnRH-induced LH levels were found.

During childhood, both serum basal and GnRH-induced FSH levels remained clearly elevated in these patients $[14,17]$. Furthermore, patients reported by Conte et al. [11] at 17 months of age, and by Lin et al. [18] at 2.3 years of age, showed high basal and LHRH-induced serum FSH levels. Therefore, the persistence of high serum basal FSH levels observed in these affected girls suggests that the minimal amounts of normal prepubertal circulating estrogens are enough to restraint pituitary FSH. Serum basal LH levels were within the normal range in all reported patients, but a hyper-response after GnRH stimulation was observed. It could be speculated that a prolonged effect of androgens or lack of estrogens during childhood might result in an irreversible maturation of the GnRH pulse generator [30].

\section{Ovarian Cyst Formation}

Large hemorrhagic cystic follicles have been described in aromatase-deficient girls during infancy and childhood [11, 14, 17] and in ArKO female mice [31]. It is remarkable that the histopathologic analysis was consistent with that of the polycystic ovary syndrome. It has been proposed that chronic exposure to abnormally high levels 
of LH stimulates ovarian cyst development [32, 33]. However, female mice that are homozygous for a targeted disruption of the FSH $\beta$-subunit gene exhibit an approximately 5 -fold increase in serum LH, but do not show signs of enlarged cystic follicles in the ovary [34], suggesting there is a role for FSH in this process as well. In the rat, granulosa cells of primary, secondary and mature follicles show intense androgen receptor expression [35]. Weil et al. [36] showed that testosterone increased follicular FSH receptors and it has been suggested that androgens, such as those present in polycystic ovary syndrome, promote follicular growth by amplifying the FSH effect. It has been proposed that this partially explains the enhanced responsiveness to gonadotropin stimulation noted in women with polycystic ovary syndrome. Therefore, we have speculated that in aromatase-deficient prepubertal girls, an amplification of FSH signaling might occur in the presence of high intraovarian androgen production and that this mechanism could be involved in the development of ovarian follicular cysts.

The usefulness of estrogen treatment during infancy and childhood in affected female patients is not clear. Mullis et al. [14] reported that low doses of estradiol in a 3 -year-old affected girl resulted in normalization of serum gonadotropins, regression of enlarged ovaries and improvement in bone mineral density (BMD). However, plasma FSH returned to pretreatment levels and ovarian size increased shortly after of estrogen withdrawal. Although the ovary is not quiescent during the prepubertal period, and a minipuberty has been described during the first 3 months of age in normal girls, there is little experience in potential side effects of chronic low-dose administration of estradiol during early prepuberty. Therefore, to prevent the risk of torsion of enlarged ovaries and ovarian cysts during infancy and early childhood, long-term treatment with a GnRH analog may be considered as a therapeutic option. However, an undesired effect of lack of gonadal hormones on BMD during infancy and early childhood has not been clearly established.

Impact on Growth, Skeletal Maturation and Bone

Homeostasis

Delay in bone maturation has been reported in aromatase deficiency [17]. Particularly, a delay in skeletal maturation was clearly evident in late prepuberty. Furthermore, an advance of bone age under estrogen replacement therapy has been reported [13], confirming the critical role of estrogens on skeletal maturation during prepubertal years.

Genotype/Phenotype Spectrum of Aromatase Deficiency
It is accepted that estrogens are important in preserving adequate BMD [37]. However, data on the role of estrogens on bone mineralization during childhood are scarce. In the patient reported by Mullis et al. [14], a low BMD was found. Moreover, BMD improved after treatment with low doses of estrogens, suggesting that minimal quantities of estrogens are also required to preserve mineral bone acquisition in early childhood. However, in the case reported by Belgorosky et al. [17], BMD was normal during the entire follow-up. The explanation could be that in this particular case a partial CP450arom deficiency, secondary to a mutation at the consensus donor splice site in the exon 5/intron 5 junction was found (table 1). Therefore, some expression of cP450arom protein might be expected, which may be enough to maintain a normal mineral bone acquisition, at least during childhood.

\section{Female Puberty}

Classic Phenotype

Classically, in complete aromatase deficiency [11, 13, $18,21]$ affected females show absence of the onset of puberty, with lack of breast development and primary amenorrhea, as well as excessive virilization. The pubertal spurt is absent and bone aging delayed. Basal and GnRHinduced LH and FSH levels are elevated. Serum androgens (testosterone and androstenedione) levels are high compared to normal values for age and stage of sexual development, whereas serum estradiol levels are extremely low. This hormonal pattern supports the concept of a primary role of estrogen, not replaced by androgens, in the feedback mechanism of gonadotropin secretion within the hypotalamo-pituitary-gonadal axis in females. Multiple bilateral ovarian cysts are also seen on pelvic ultrasound. In the case reported by Morishima et al. [13], several cystic masses with multiple lobules were found on abdominal exploration.

Variable or Non-Classic Phenotypes

Recently, Lin et al. [18] have reported the presence of variable, or non-classic, phenotypes in 2 affected females. A 13.5-year-old patient showed findings compatible with the complete form of aromatase deficiency, except for the presence of spontaneous breast development that did not progress further than Tanner stage 2, and a pubertal size uterus with an endometrial stripe. The second female studied had spontaneous breast development that progressed to Tanner stage 4 at 14 year of age. Since she was raised as a male and reported male gender identity, role and orientation, salpingo-oophorectomy and hysterec- 
tomy were performed in an attempt to reduce sex hormone secretion and arrest breast development (table 1).

The patient described by Belgorosky et al. [17], unexpectedly started with spontaneous breast development (Tanner stage 2) at the age of 7.7 years, and a slight elevation of serum estradiol levels was detected.

The cases described by Lin et al. [18] and Pepe et al. [19] illustrate that phenotypic variability may occur in aromatase insufficiency in humans. Low levels of residual aromatase activity may be associated with breast development and estrogen biosynthesis, specially when circulating androgen substrate concentrations are elevated allowing for a phenotype of partial cP450arom deficiency.

Although detailed psychosexual studies have not been reported, female psychosexual orientation has been observed in most 46,XX subjects, except for the patient published by Lin et al. [18]. It is unclear whether pre- and postnatal androgen exposure coupled with relative estrogen insufficiency, a unique feature of aromatase deficien$c y$, is important in programming sexual orientation, or social and cultural influences predominate.

During puberty and adulthood, signs and symptoms of estrogen deficiency become evident. In pubertal females with aromatase deficiency, daily estrogen replacement therapy associated with a progesterone-like hormone not only resulted in breast development, menarche and maintenance of menses, growth spurt and fused epiphyses, but also in decreases in plasma concentration of gonadotropins and androgens with subsequent regression of ovarian cysts $[11,13,18]$. Thus, treatment confirmed the critical role of estrogens on the hypothalamicpituitary-ovarian axis and on bone skeletal maturation. Although no data exist on bone mineral mass in affected females on estrogen replacement therapy, it is expected that estrogen treatment might be important to improve bone mineral accretion.

\section{Insulin Sensitivity and Lipid Profile}

Insulin resistance, abnormal lipid profile, as well as clinical features similar to the metabolic syndrome have been described in aromatase-deficient adult men. Improvement of these parameters with estrogen therapy has been reported [22-24, 29, 38]. However, in affected female patients, the relationship between carbohydrate metabolism, lipid profile and estrogen deficiency has not been clearly defined. There is only 1 available report, by Lin et al. [18], of an affected 14.6-year-old girl, who had a mild dyslipidemia and whose metabolic profile normalized under estrogen therapy.
Insulin resistance and glucose intolerance at the age of 9 years, associated with high serum androgen and FSH levels have been reported in an affected girl with early signs of puberty by Guercio et al. [39]. No response to estrogen replacement therapy or metformin treatment was observed. She developed Type 2 diabetes mellitus during follow up. Lipid profile, liver enzyme levels and liver ultrasound were normal. In this patient, GnRHa administration for 1 year resulted in marked decreases in gonadotropin and serum androgen level, but severe insulin resistance persisted. This lack of response to estrogen replacement and androgen withdrawal suggested that the metabolic abnormality was irreversible. The authors proposed that in females the androgen increase and/or lack of estrogens during fetal life might have altered the mechanism of fetal programming of insulin sensitivity.

\section{Aromatase Deficiency in an Affected Infant Boy}

Deladoëy et al. [25] reported the only affected infant boy described in the literature. His mother suffered from progressive virilization during pregnancy but at birth, as expected, his external genitalia were normal. In contrast to affected infant girls, hormonal studies carried out when he was 2 month old revealed that basal and GnRHstimulated FSH levels were normal despite low serum estrogen concentrations, suggesting that estrogens are not involved in the regulation of FSH secretion in infant boys. Hence, a gender-specific negative feedback mechanism, at least during infancy and early childhood, has been suggested [25]. Moreover, in this aromatase-deficient boy, a normal serum inhibin B level for sex and age was found. Hence, it had been proposed that inhibin B might be the major contributor in the regulation of serum FSH secretion in normal infant males. The fact that in the affected boy free testosterone and androstenedione levels were very high at 2 weeks of postnatal life, followed by a decrease to the normal range during the first month of age suggests a role of cP450arom in fetal and newborn testicular function.

It has been described that cP450arom is highly expressed in fetal and neonatal human testes compared to testes of older prepubertal ages. Berensztein et al. [40] suggested that aromatase activity might play a role in modulating testosterone secretion; the high aromatase expression of human neonatal Leydig cells decreased at 2-4 months of age whereas peak testosterone secretion occurred during the postnatal testicular activation period.

Berensztein et al. [41] also found that during the newborn period, there is a vigorous increment in testicular 
cell populations. This cell mass growth seems to be mainly mediated by decreased apoptosis. It has been postulated that these changes, taking place during the neonatal period, may be important to define testicular function in adults. The factors that modulate this growth are not known, but aromatase might play a role.

On the other hand, in aromatase-deficient adult males, testis volume has been reported to be variable. In a few patients, decreased motility and reduced numbers of spermatozoa have been observed on sperm analysis. Therefore, testis function in aromatase-deficient adults is not well defined.

\section{Final Comments}

Patients with cP450arom deficiency represent another 'experiment of nature' that has proven to be a fertile source of knowledge of estrogen physiology and pathology, particularly on the roles of estrogens and bone mat- uration, gonadotropin modulation in both sexes, ovarian cyst formation, testicular function and glucose and lipid metabolism. However, many questions remain to be answered, such as the possible existence of a window period for estrogen action in early life, in both sexes. In females, the increment of androgens and/or lack of estrogens during fetal life might be involved in a mechanism of fetal programming on insulin sensitivity and on the hypothalamic-pituitary-gonadal axis. In males, lack of local estrogen production in fetal or neonatal testes could alter adult testicular development and function.

\section{Acknowledgments}

We are grateful to Pablo Ramirez for the expert collaboration and illustration designs. The study was supported by grants from Consejo Nacional de Investigaciones Científicas y Técnicas (CONICET) and Fondo para la Investigación Científica y Tecnologica (FONCYT) of Argentina, and from Pfizer Endocrine Care.

\section{References}

1 Belgorosky A, Rivarola MA: Physiology and pathophysiology of estrogens: lessons from pediatric patients with complete aromatase deficiency. Endocrinologist 2004;14:1-8.

-2 Jones ME, Boon WC, McInnes K, Maffei L, Carani C, Simpson ER: Recognizing rare disorders: aromatase deficiency. Nat Clin Pract Endocrinol Metab 2007;3:414-421.

3 Meinhardt U, Mullis PE: The aromatase cytochrome P-450 and its clinical impact. Horm Res 2002;57:145-152.

-4 Zirilli L, Rochira V, Diazzi C, Caffagni G, Carani C: Human models of aromatase deficiency. J Steroid Biochem Mol Biol 2008;109: 212-218.

5 Jones M, Boom W, Proietto J, Simpson ER: Of mice and men: the evolving phenotype of aromatase deficiency. Trends Endocrinol Metab 2006; 17:53-62.

-6 Rochira V, Balestrieri A, Madeo B, Spaggiari A, Carani C: Congenital estrogen deficiency in men: a new syndrome with different phenotypes; clinical and therapeutic implications in men. Mol Cell Endocrinol 2002;193: 19-28.

7 Means GD, Mahendroo MS, Corbin CJ, Mathis JM, Powell FE, Mendelson CR, Simpson ER: Structural analysis of the gene encoding human aromatase cytochrome P450 , the enzyme responsible for estrogen biosynthesis. J Biol Chem 1989;264:1938519391.
-8 Graham-Lorence S, Amarneh B, White RE, Peterson JA, Simpson ER: A three-dimensional model of aromatase cy tochrome P450. Protein Sci 1995;4:1065-1080.

-9 Shozu M, Akasofu K, Harada T, Kubota Y: A new cause of female pseudohermaphroditism: placental aromatase deficiency. J Clin Endocrinol Metab 1991;72:560-566.

10 Harada N, Ogawa H, Shozu M, Yamada K: Genetic studies to characterize the origin of the mutation in placental aromatase deficiency. Am J Hum Genet 1992;51:666-672.

11 Conte FA, Grumbach MM, Ito Y, Fisher CR, Simpson ER: A syndrome of female pseudohermaphrodism, hypergonadotropic hypogonadism, and multicystic ovaries associated with missense mutations in the gene encoding aromatase (P450arom). J Clin Endocrinol Metab 1994;78:1287-1292.

12 Ito Y, Fisher CR, Conte FA, Grumbach MM, Simpson ER: Molecular basis of aromatase deficiency in an adult female with sexual infantilism and polycystic ovaries. Proc Natl Acad Sci USA 1993;90:11673-11677.

13 Morishima A, Grumbach MM, Simpson ER, Fisher C, Qin K: Aromatase deficiency in male and female siblings caused by a novel mutation and the physiological role of estrogens. J Clin Endocrinol Metab 1995;80: 3689-3698.
14 Mullis PE, Yoshimura N, Kuhlmann B, Lippuner K, Jaeger P, Harada H: Aromatase deficiency in a female who is compound heterozygote for two new point mutations in the P450arom gene: impact of estrogens on hypergonadotropic hypogonadism, multicystic ovaries, and bone densitometry in childhood. J Clin Endocrinol Metab 1997;82: 1739-1745.

15 Portrait-Doyen, Forest MG, Nicolino M, Morel Y, Chatelain PC: Female pseudohermaphortidism resulting from aromatase (P450arom) deficiency associated with a novel mutation (R457X) in the CYP19 gene. Horm Res 1996;46(suppl 2):14

16 Ludwig M, Beck A, Wickert L, Bolkenius U, Tittel B, Hinkel K, Bidlingmaier F: Female pseudohermaphroditism associated with a novel homozygous G-to-A (V370-to-M) substitution in the $\mathrm{P}-450$ aromatase gene. J Pediatr Endocrinol Metab 1998;11:657-664.

17 Belgorosky A, Pepe C, Marino R, Guercio G, Saraco N, Vaiani E, Rivarola MA: Hypothalamic-Pituitary-Ovarian axis during infan$c y$, early and late prepuberty in an aromatase-deficient girl who is a compound heterocygote for two new point mutations of the CYP19 gene. J Clin Endocrinol Metab 2003;88:5127-5131.

- 18 Lin L, Ercan O, Raza J, Burren CP, Creighton SM, Auchus RJ, Dattani MT, Achermann JC: Variable phenotypes associated with aromatase (CYP19) insufficiency in humans. J Clin Endocrinol Metab 2007;92:982-990. 
-19 Pepe C, Saraco, Baquedano S, Guercio G, Vaiani E, Marino R, Pandey A, Flück C, Rivarola MA, Belgorosky A: The cytochrome P450 aromatase lacking exon 5 is associated with a phenotype of non-classic aromatase deficiency, and it is also present in normal human steroidogenic tissues. Clin Endocrinol (Oxf) 2007;67:698-705.

20 Harada N, Ogawa H, Shozu M, Yamada K, Suhara K, Nishida E, Takagi Y: Biochemical and molecular genetic analyses on placental aromatase (P-450AROM) deficiency. J Biol Chem 1992;267:4781-4785.

21 Richter-Unruh A, Schmidt M, Verhoef-Post M, Themmen APN: Aromatase deficiency: delayed puberty in a German girl is due to 2 new mutations of the CYP19 gene. 90th Annl Meet Endocrine Soc, San Francisco, 2008; abstr P2-590.

-22 Carani C, Qin K, Simoni M, Faustini-Fustini M, Serpente S, Boyd J, Korach KS, Simpson ER: Effect of testosterone and estradiol in a man with aromatase deficiency. N Engl J Med 1997;337:91-95.

-23 Herrmann BL, Saller B, Janssen OE, Gocke P, Bockisch A, Sperling H, Mann K, Broecker M: Impact of estrogen replacement therapy in a male with congenital aromatase deficiency caused by a novel mutation in the CYP19 gene. J Clin Endocrinol Metab 2002; 87:5476-5484.

-24 Maffei L, Murata Y, Rochira V, Tubert G, Aranda C, Vazquez M, Clyne C, Davis S, Simpson ER, Carani C: Dysmetabolic syndrome in a man with a novel mutation of the aromatase gene: effects of testosterone, alendronate and estradiol treatment. J Clin Endocrinol Metab 2004;89:61-70.

-25 Deladoëy J, Fluck C, Bex M, Yoshimura N, Harada N, Mullis PE: Aromatase deficiency caused by a novel P450arom gene mutation: impact of absent estrogen production on serum gonadotropin concentration in a boy. J Clin Endocrinol Metab 1999;84:4050-4054.
26 Bouillon R, Bex M, Vanderschueren D, Boonen S: Estrogens are essential for male pubertal periosteal bone expansion. J Clin Endocrinol Metab 2004;89:6025-6029.

27 Pura M, Mittre H, Carreau S, Kottler ML: Clinical findings in an adult man with a novel mutation in the aromatase gene. 85th Ann Meet Endocrine Soc, Philadelphia, 2003; abstr P1-467.

28 Maffei L, Rochira V, Zirilli L, Antunez P, Aranda C, Fabre B, Simone ML, Pignatti E, Simpson ER, Houssami S, Clyne CD, Carani C: A novel compound heterozygous mutation of the aromatase gene in an adult man: reinforced evidence on the relationship between congenital oestrogen deficiency, adiposity and the metabolic syndrome. Clin Endocrinol (Oxf) 2007;67:218-224.

29 Lanfranco F, Zirilli L, Baldi M, Pignatti E, Corneli G, Ghigo E, Aimaretti G, Carani C, Rochira V: A novel mutation in the human aromatase gene: insights on the relationship among serum estradiol, longitudinal growth and bone mineral density in an adult man under estrogen replacement treatment. Bone 2008;43:628-635.

30 Belgorosky A, Rivarola MA: Irreversible increase of serum IGF-1 and IGFBP-3 levels in $\mathrm{GnRH}$-dependent precocious puberty of different etiologies: implications for the onset of puberty. Horm Res 1998;49:226-232.

31 Britt KL, Drummond AE, Cox VA, Dyson M Wreford NG, Jones ME, Simpson ER, Findlay JK: An age-related ovarian phenotype in mice with targeted disruption of the CYP19 (aromatase) gene. Endocrinology 2000;141: 2614-2623.

32 Risma KA, Clay CM, Nett TM, Wagner T, Yun J, Nilson JH: Targeted overexpression of luteinizing hormone in transgenic mice leads to infertility, polycystic ovaries, and ovarian tumors. Proc Natl Acad Sci USA 1995;92:1322-1326.

33 Risma KA, Hirshfield AN, Nilson JH: Elevated luteinizing hormone in prepubertal transgenic mice causes hyperandrogenemia precocious puberty, and substantial ovarian pathology. Endocrinology 1997;138:35403547.
34 Kumar TR, Wang Y, Lu N, Matzuk MM: Follicle stimulating hormone is required for ovarian follicle maturation but not male fertility. Nat Genet 1997;15:201-204.

35 Pelletier G, Labrie C, Labrie F: Localization of oestrogen receptor, oestrogen receptor $\beta$ and androgen receptors in the rat reproductive organs. J Endocrinol 2000;165:359-370.

-36 Weil S, Vendola K, Zhou J, Bondy CA: Androgen and follicle-stimulating hormone interactions in primate ovarian follicle development. J Clin Endocrinol Metab 1999;84: 2951-2956.

37 Bilezikian JP, Morishima A, Bell J, Grumbach MM: Increased bone mass as a result of estrogen therapy in a man with aromatase deficiency. N Engl J Med 1998;339:599-603.

-38 Herrmann BL, Janssen OE, Hahn S, Broecker-Preuss M, Mann K: Effects of estrogen replacement therapy on bone and glucose metabolism in a male with congenital aromatase deficiency. Horm Metab Res 2005;37:178183.

39 Guercio G, Di Palma MI, Pepe C, Saraco NI, Prieto M, Saure C, Mazza C, Rivarola MA, Belgorosky A: Metformin, estrogen replacement therapy and gonadotropin inhibition fail to improve insulin sensitivity in a girl with aromatase deficiency. Horm Res 2009, in press.

40 Berensztein EB, Baquedano MS, Gonzalez CR, Saraco NI, Rodriguez J, Ponzio R, Rivarola MA, Belgorosky A: Expression of aromatase, estrogen receptor alpha and beta, androgen receptor, and cytochrome $\mathrm{P}$ $450 \mathrm{scc}$ in the human early prepubertal testis. Pediatr Res 2006;60:740-744.

-41 Berensztein EB, Sciara MI, Rivarola MA, Belgorosky A: Apoptosis and proliferation of human testicular somatic and germ cells during prepuberty: high rate of testicular growth in newborns mediated by decreased apoptosis. J Clin Endocrinol Metab 2002;87: 5113-5118 